ARTICLE

https://doi.org/10.1038/s41467-019-08553-y

\title{
Emergence of the structure-directing role of f-orbital overlap-driven covalency
}

\author{
Erli Lu', Saira Sajjad ${ }^{1,2}$, Victoria E.J. Berryman', Ashley J. Wooles',
} Nikolas Kaltsoyannis (i) ${ }^{1} \&$ Stephen T. Liddle (i) ${ }^{1}$

FEUDAL (f's essentially unaffected, d's accommodate ligands) is a longstanding bonding model in actinide chemistry, in which metal-ligand binding uses 6d-orbitals, with the $5 f$ remaining non-bonding. The inverse-trans-influence (ITI) is a case where the model may break down, and it has been suggested that ionic and covalent effects work synergistically in the ITI. Here, we report an experimentally grounded computational study that quantitatively explores the ITI, and in particular the structure-directing role of f-orbital covalency. Strong donor ligands generate a cis-ligand-directing electrostatic potential (ESP) at the metal centre. When f-orbital participation, via overlap-driven covalency, becomes dominant via short actinide-element distances, this ionic ESP effect is overcome, favouring a trans-liganddirected geometry. This study contradicts the accepted ITI paradigm in that here ionic and covalent effects work against each other, and suggests a clearly non-FEUDAL, structuredirecting role for the f-orbitals.

\footnotetext{
${ }^{1}$ School of Chemistry, The University of Manchester, Oxford Road, Manchester M13 9PL, UK. ${ }^{2}$ Department of Chemistry, COMSATS Institute of Information Technology, Abbottabad, 22060 Abbottabad, Pakistan. These authors contributed equally: Erli Lu, Saira Sajjad, Victoria E.J. Berryman. Correspondence and requests for materials should be addressed to N.K. (email: nikolas.kaltsoyannis@manchester.ac.uk) or to S.T.L. (email: steve.liddle@manchester.ac.uk)
} 
O ne of the most fascinating, enduring, and controversial topics in molecular actinide science is the continuously debated nature and extent of the chemical bonding of the early members of the series, and in particular uranium, and how this relates to structure and periodic trends within the context of the entire Periodic Table ${ }^{1-19}$. The role of s-, p-, and d-orbitals in chemical bonding and how this relates to the geometries of main group and transition metal complexes is now well understood. For lanthanides, the bonding is usually described as overwhelmingly ionic and non-directional with little orbital contribution; however, where covalency is invoked, for example where the trans-influence (TI) has been observed ${ }^{20-30}$, it is usually d-orbitals that are involved $27,31,32$. By contrast, for the early actinides there is still debate over the extent and tensioning of $\mathrm{f}$ - vs d-orbital character ${ }^{7,8,14}$ and, given that electrostatics are generally accepted as the dominant feature of the bonding, the structure directing role of the $5 \mathrm{f}$-orbitals remains a moot point ${ }^{33}$.

A longstanding conceptual bonding model in actinide chemistry is Bursten's FEUDAL (f's essentially unaffected, d's accommodate ligands). This model advances the notion that actinides bind primarily using their d-orbitals and the f-orbitals remain mainly non-bonding ${ }^{34,35}$. This view seems to hold for ions like uranium when bonded to expansive ligands that have low angular requirements, e.g. $\mathrm{C}_{5-8}$-arenes ${ }^{36-41}$, but in recent years this has been increasingly challenged when small ligands with more acute angular requirements, e.g. nitrides, are considered ${ }^{42,43}$. However, although this model considers the issue of orbital interactions it does not directly address whether f-orbitals are structure directing, but their characterisation as 'unaffected' implicitly suggests no structure-directing role. Moreover, there are hints in the literature that FEUDAL sometimes breaks down in scenarios where structure-directing effects involving f-orbitals are invoked. The longstanding, preeminent example of this is the inverse-transinfluence (ITI) ${ }^{44-46}$, where strongly donating ligands are preferentially found to be trans to one another. The most prevalent example of this is uranyl; e.g. in $\left[\mathrm{UO}_{2} \mathrm{Cl}_{2}\left(\mathrm{OPPh}_{3}\right)_{2}\right]$ the two oxos are mutually trans in direct contrast to $\left[\mathrm{MoO}_{2} \mathrm{Cl}_{2}\left(\mathrm{OPPh}_{3}\right)_{2}\right]$ where they are $c i s^{47-50}$. In recent years a variety of non-uranyl complexes that seem to exhibit the ITI have been reported, usually with uranium in oxidation states $\mathrm{V}$ and VI and with nitride or oxo ligands ${ }^{43,51-56}$. Two hypotheses have been developed to account for the ITI $45,46,57-59$. From an orbital perspective, it is proposed that the $6 \mathrm{p}$-orbitals of early actinides are semi-core, and therefore semi-valence, and can donate electron density into vacant 5 f-orbitals; thus, an electron hole forms that is compensated by increased electron donation from a trans ligand. Alternatively, a polarisation argument can be employed; when the parity of overlapping orbitals is $u-g$, as is the case with p-d orbitals, a dipolar arrangement at the metal disfavours trans and stabilises cis positions, whereas when the parity is the same, e.g. $u-u$ for $\mathrm{p}-\mathrm{f}$ orbitals, then the charge distribution is quadrupolar with trans favoured and cis disfavoured. It should be noted that these working theories are based on logical, but suppositional, arguments, and although the majority of studies have focussed on establishing the role of the $6 \mathrm{p}$ - and/or $5 \mathrm{f}$-orbitals, their precise roles remain somewhat nebulous. Furthermore, although the traditional view of the ITI is that ionic and covalent effects compete with one another, it has been suggested that this is misleading ${ }^{33}$, and that ionic and covalent effects are actually working together synergistically.

At this point, a clarification of the term covalency is merited ${ }^{60-62}$. Covalency, that is the mixing coefficient, is proportional to the spatial overlap of the orbitals divided by the difference in their energies, and these two parameters are independent of one another ${ }^{7,8}$. So, covalency can increase by increased spatial overlap or by reduction in the difference of parent atomic orbital energies.
The latter, which is called near-energy driven covalency, is a perfectly valid definition of covalency when framed in context, but chemical bonding carries the connotation of orbital overlap resulting in electron density building up in the inter-nuclear region. The former is called overlap-driven covalency, and it is on this aspect that discussions in this paper will focus.

We recently reported, Fig. 1, an extension of the ITI to tetravalent cerium, uranium, and thorium trans bis(carbene) complexes $(\mathbf{1 C e}, \mathbf{1 U}, \mathbf{1 T h})^{62}$ and latterly found that in carbene-imido derivatives of uranium, cis geometries were overwhelmingly favoured (2UNHRK and 2UBIPY) ${ }^{63,64}$. It is important to note that in the former the trans disposition is enforced by ligand steric constraints yet the trans carbenes are strongly bound to the metals with short $\mathrm{M}=\mathrm{C}$ bond distances, but in the latter even when steric constraints are removed the cis geometry dominates. Since uranium often uses more $5 \mathrm{f}$ - than $6 \mathrm{~d}$-orbital character in its bonding, but the reverse is usually found for thorium, we prepared analogous thorium carbene-imido complexes. Again, a cis geometry is preferred, which spurred us to survey the inherent cis or trans preferences for carbene-carbene, carbene-imido, and carbene-oxo ligand combinations for cerium, uranium, and thorium. Though many systems indeed prefer cis geometries, we notably find that the cerium and uranium oxo systems go against this trend and in fact prefer trans geometries. This study puts the original proposition of the ITI on a quantified, firm footing and reveals that the electrostatic potential (ESP) surface around the metal centre directs the cis geometries. This first concerted application of ESP arguments to this issue reveals that d-orbital participation is in fact not the driving force for cis geometries, but opportunistically results from ESPs. When f-orbital participation, and associated overlap-driven covalency, becomes dominant, the ionic effect is overcome and a trans geometry is favoured. This study therefore demonstrates that ionic and covalent effects work against each other in cases where the structure-directing role of $\mathrm{f}$ orbitals is confirmed, the latter aspect challenging the generality of the FEUDAL model.

\section{Results}

Synthesis, characterisation, and solid state structures. With $1 \mathrm{M}$ $(\mathrm{M}=\mathrm{Ce}, \mathrm{U}, \mathrm{Th})$ and 2UNHRK and 2UBIPY reported ${ }^{62-64}$, we sought to prepare the analogous $\mathrm{R}_{2} \mathrm{C}=\mathrm{Th}^{\mathrm{IV}}=\mathrm{NCPh}_{3}(2 \mathrm{Th}, \mathrm{R}=$ $\mathrm{Ph}_{2} \mathrm{PNSiMe}_{3}$ ) complexes, in order to now map out the TI/ITI structural influences across the $\mathrm{C}=\mathrm{M}^{\mathrm{IV}}=\mathrm{E}\left(\mathrm{E}=\mathrm{CR}_{2}, \mathrm{NCPh}_{3}\right)$ series, Fig. 2. It is noteworthy that in comparison with the burgeoning nature of uranium-ligand multiple bond species $3,6,12-14$, thorium-ligand multiple bond species are less developed. Indeed, for thorium 2-metalla-allenes, despite their significant importance as relatives of $\mathrm{ThO}_{2}$, two homoleptic thorium-bis(carbenes) are the only such species in the literature ${ }^{62,65}$ and there are no heteroleptic thorium-2-metalla-allenes. The previously reported thorium-carbene-bis(alkyl) [ $\left.\mathrm{Th}^{\mathrm{IV}}\left(\mathrm{BIPM}^{\mathrm{TMS}}\right)\left(\mathrm{CH}_{2} \mathrm{SiMe}_{3}\right)_{2}\right](3)^{62}$, which has a pre-installed $\mathrm{Th}=\mathrm{C}$ double bond interaction, was found to be a suitable precursor to preparing $\mathrm{C}=\mathrm{Th}^{\mathrm{IV}}=\mathrm{N}$ linkages, Fig. 2 (see Supplementary Information). Complex 3 is straightforwardly converted, via the diamide (4) or alkyl-amide (5) into 2ThBIPY or 2ThNHRK, respectively, which bear the desired $\mathrm{C}=\mathrm{Th}^{\mathrm{IV}}=\mathrm{N}$ unit, via two-step syntheses that involve deprotonations facilitated by external (for 2ThNHRK) or internal (for 2ThBIPY) Brønsted bases, and these complexes are isolated as red crystalline solids in satisfactory yields. The formulations of 2ThNHRK and 2ThBIPY are supported by NMR, IR, and optical spectroscopies, and elemental analyses (see Supplementary Figures 1 to 14 ).

Beyond the spectroscopic data, the structures of 2ThNHRK and 2ThBIPY are unambiguously confirmed by X-ray single 

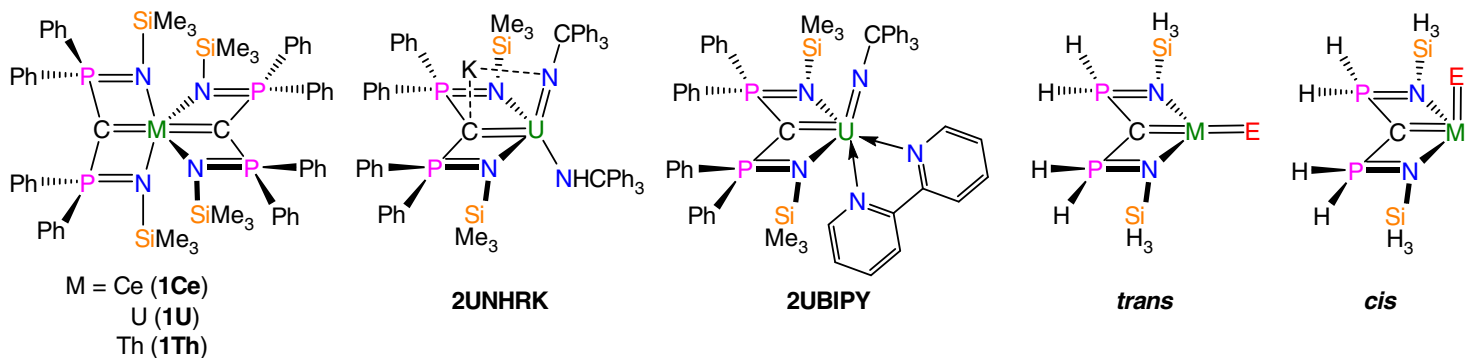

Th (1Th)

Fig. 1 Carbene complexes. Previously reported work 63,64 and trans and cis models studied in this work
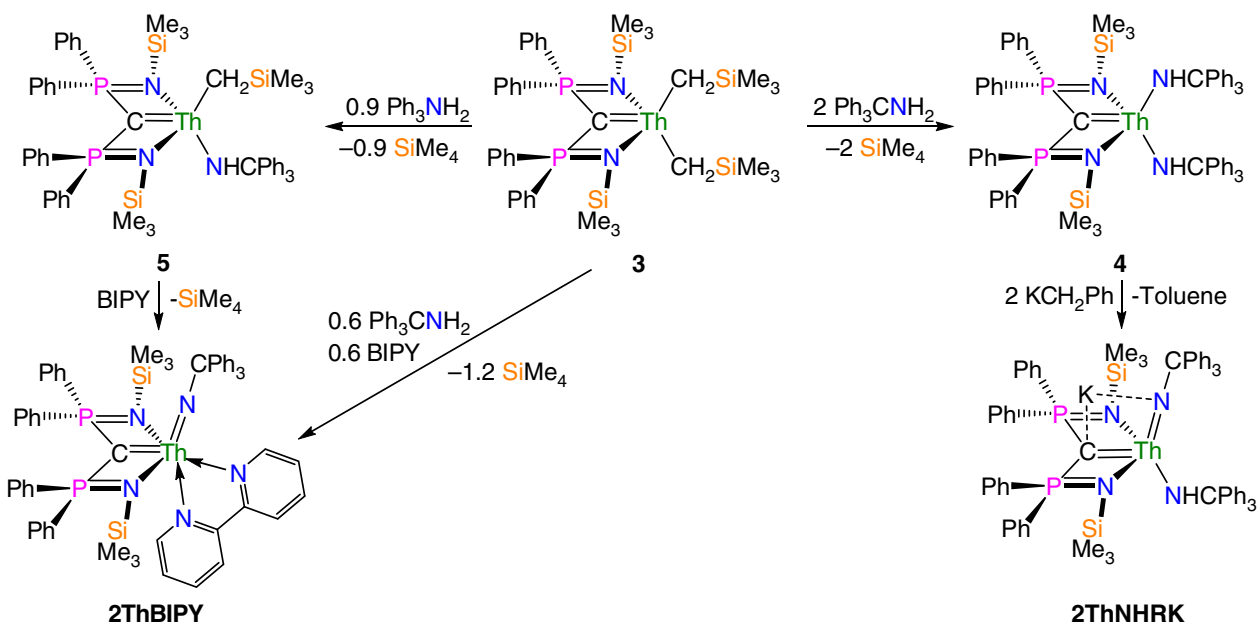

2ThNHRK

Fig. 2 Synthesis of complexes 2ThBIPY and 2ThNHRK. The known dialkyl complex $\mathbf{3}$ can be reacted two equivalents of trityl-amine by protonolysis to give the diamide complex $\mathbf{4}$. Complex $\mathbf{4}$ when treated with two equivalent of benzyl potassium (to maximise the yield, a stoichiometric amount of benzyl potassium gives lower yields) converts to the amide-imide complex 2ThNHRK. Complex $\mathbf{3}$ can alternatively be reacted with a sub-stoichiometric quantity of trityl-amine (to suppress ligand-redistribution reactions) to give, via protonolysis, the mixed alkyl-amide complex $\mathbf{5}$. Complex $\mathbf{5}$ undergoes $\alpha$-hydrogen abstraction on addition of BIPY to give 2ThBIPY

crystal diffraction, Fig. 3. The salient structural feature of these complexes is the cis- $\mathrm{C}=\mathrm{Th}^{\mathrm{IV}}=\mathrm{N}$ units $[\mathrm{C}=\mathrm{Th}=\mathrm{N}$ for 2ThNHRK and 2ThBIPY $=107.08(19)$ and $110.90(9)^{\circ}$, respectively], which is similar to $\mathbf{2} \mathbf{U}$ analogues, suggesting the presence of a TI. Structurally speaking, though a potassium ion is intimately coordinated in the structure of 2ThNHRK the Th= $\mathrm{N}_{\text {imide }}$ and $\mathrm{Th}=\mathrm{C}_{\text {carbene }}$ bonds in this complex are little disturbed from what might be anticipated for formal thorium-nitrogen and -carbon double bond interactions [Th $=\mathrm{N}_{\text {imide }}$ for 2ThNHRK and 2ThBIPY $=2.109(5)$ and $2.067(2) \AA$; $\mathrm{Th}=\mathrm{C}_{\text {carbene }}$ for 2ThNHRK and 2ThBIPY $=2.564(6)$ and 2.558(3) $\AA$, respectively]. The Th- $\mathrm{N}_{\mathrm{BIPY}}, \mathrm{C}-\mathrm{N}$ and $\mathrm{C}-\mathrm{C}$ bond lengths in the bipyridine fragment of 2ThBIPY are consistent only with a neutrally coordinated BIPY ligand ${ }^{66}$.

Computational geometry optimisations. Building on our previous study of 2 UBIPY ${ }^{64}$, we investigated a family of nine metalla-allene model systems $[\mathrm{C}]=\mathrm{M}=\mathrm{E} \quad([\mathrm{C}]=\mathrm{C}$ $\left.\left(\mathrm{PH}_{2} \mathrm{NSiH}_{3}\right)_{2} ; \mathrm{M}=\mathrm{Ce}^{\mathrm{IV}}, \mathrm{Th}^{\mathrm{IV}}, \mathrm{U}^{\mathrm{IV}} ; \mathrm{E}=\mathrm{C}\left(\mathrm{CH}_{3}\right)_{2}, \mathrm{NCH}_{3}, \mathrm{O}\right)$, with a particular focus on the C-M-E angle, using the Gaussian09 code $^{67}$ with two density functional approximations (DFAs). We used the generalised gradient approximation (GGA), $\mathrm{PBE}^{68,69}$, and related hybrid, $\mathrm{PBE}^{70}$; these DFAs are ideal as $\mathrm{PBE}$ has recently been shown to give accurate geometries in an extensive benchmarking study of organouranium systems ${ }^{71}$, and the GGA BP86 performs better than B3LYP and certain Minnesota functionals for some uranium bis carbene complexes ${ }^{72}$, and PBE0 is known to give improved energetics and has been previously applied by us to the study of a uranium(IV)-carbeneimido complexes ${ }^{63,64}$. Model complexes were sterically truncated and void of potassium ions and co-ligands to isolate electronic effects from steric constraints, and the final equilibrium geometries are obtained irrespective of whether the starting geometry is cis or trans with respect to the $[\mathrm{C}]=\mathrm{M}=\mathrm{E}$ angle. The results are collected in Supplementary Tables 1 to 5, from which it can be seen that there is little difference between the two DFAs. All the systems with $\mathrm{E}=\mathrm{C}\left(\mathrm{CH}_{3}\right)_{2}$ and $\mathrm{NCH}_{3}$ adopt a cis geometry. However, for the oxo complexes only $[\mathrm{C}]=\mathrm{Th}=\mathrm{O}$ has a cis conformation $\left(\mathrm{C}-\mathrm{Th}-\mathrm{O}\right.$ angle $\left.=116.8 / 116.6^{\circ}\right)$, whereas $[\mathrm{C}]=\mathrm{Ce}$ $=\mathrm{O}$ and $[\mathrm{C}]=\mathrm{U}=\mathrm{O}$ prefer trans geometries, with $\mathrm{C}-\mathrm{M}-\mathrm{O}$ angles of $165.1 / 162.2^{\circ}$ and $176.9 / 176.4^{\circ}$, respectively, at the PBE0/ PBE level.

Computational total energy surface scans. To further probe the energetic preference for cis or trans conformations, total selfconsistent field (SCF) energy surfaces were explored as a function of the C-M-E angle, as defined by the trans and cis models on the right-hand side of Chart 1. All geometric parameters were relaxed except this angle, which was perturbed in $5^{\circ}$ increments from the optimised geometry. The resulting plots for the $\mathrm{E}=\mathrm{C}\left(\mathrm{CH}_{3}\right)_{2}$, $\mathrm{NCH}_{3}$ and $\mathrm{O}$ systems are shown in Fig. $4 \mathrm{a}-\mathrm{c}$, respectively. The data for $[\mathrm{C}]=\mathrm{M}=\mathrm{C}\left(\mathrm{CH}_{3}\right)_{2}$ and $[\mathrm{C}]=\mathrm{M}=\mathrm{NCH}_{3}$ are similar to one another; in both cases the Th molecule has the largest preference for a cis geometry, followed by $\mathrm{U}$ and then $\mathrm{Ce}$, which are similar. We have attempted to quantify these preferences by locating transition states (TSs), starting from the highest points of the SCF 

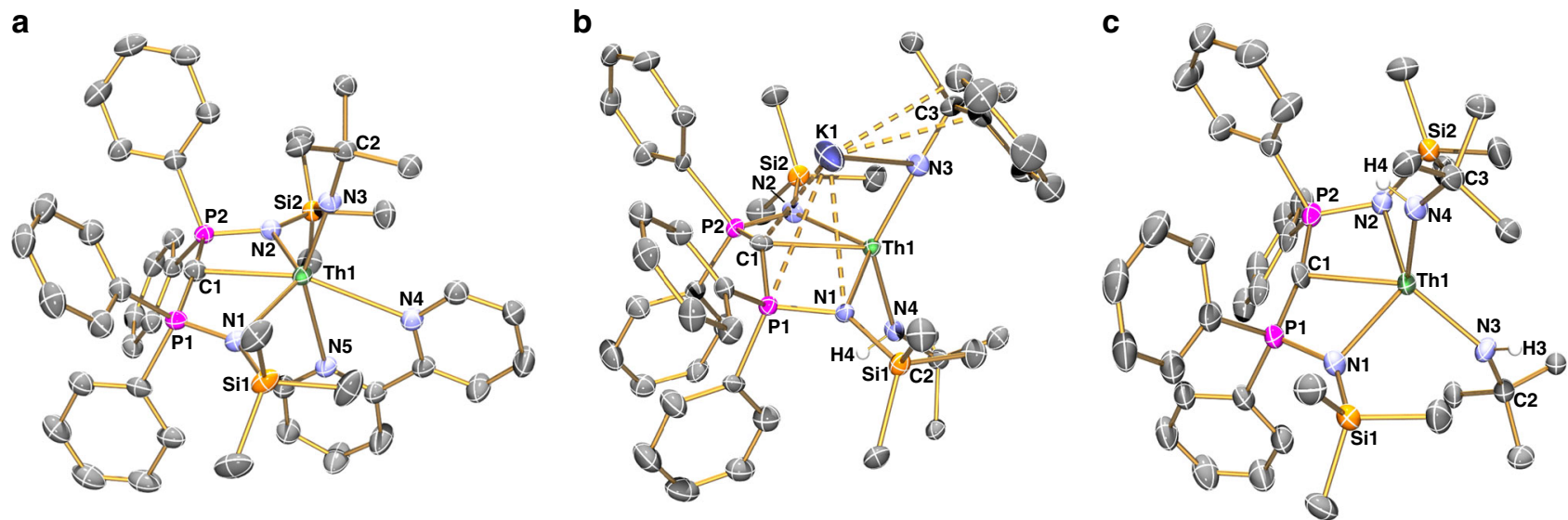

Fig. 3 Molecular structures of the molecules reported in this study. a 2ThBIPY, b 2ThNHRK, and c 4. Structures were determined at $120 \mathrm{~K}$ and are shown with displacement ellipsoids set to $40 \%$. Hydrogen atoms, minor disorder components, lattice solvent, and non-ipso trityl-phenyl ring carbon atoms, unless involved in a novel binding interaction, are omitted for clarity

energy scans; the available data are presented in Supplementary Table 2. In $[\mathrm{C}]=\mathrm{Th}=\mathrm{NCH}_{3}$, the maximum of the energy surface scan is at $164.7^{\circ}$, and this point is $27.1 \mathrm{~kJ} \mathrm{~mol}^{-1}$ above the optimised structure (Fig. 4b). A coupled cluster $(\operatorname{CCSD}(\mathrm{T}))$ singlepoint calculation at the PBE0 geometry of the maximum energy point lies $27.0 \mathrm{kJmol}^{-1}$ above that of the fully optimised geometry, providing excellent post-Hartree-Fock validation of the PBE0 approach. The very small T1 diagnostic $(0.017)$ at both the fully optimised and maximum energy point structures indicates that the electronic structure is well represented by a single configuration, providing further justification of a DFT-based analysis.

In contrast to the $\mathrm{C}$ - and $\mathrm{N}$-based systems, the total energy scans for the $[\mathrm{C}]=\mathrm{M}=\mathrm{O}$ model complexes (Fig. 4c), reveal the $\mathrm{Ce}$ and $\mathrm{U}$ molecules to be most stable at large C-M-O angles. $[\mathrm{C}]=\mathrm{U}=\mathrm{O}$ is particularly interesting, with a shallow local minimum at a C-U-O angle of $\sim 122^{\circ}$, which interestingly is close to the lowest energy optimised geometry of $[\mathrm{C}]=\mathrm{Th}=\mathrm{O}$. The transition state for the cis-trans isomerisation for this complex (at $142.2^{\circ}$ ) is only $3.3 \mathrm{~kJ} \mathrm{~mol}^{-1}$ above the fully optimised structure. For $[\mathrm{C}]=\mathrm{Ce}=\mathrm{O}$, there is no local minimum at a cis geometry; however, reducing the angle to $120^{\circ}$ incurs an energy change of less than $5.0 \mathrm{~kJ} \mathrm{~mol}^{-1}$. Similarly, the cis/trans isomerisation barrier for $[\mathrm{C}]=\mathrm{Th}=\mathrm{O}$ is reduced by approximately half relative to $[\mathrm{C}]=\mathrm{Th}=\mathrm{C}\left(\mathrm{CH}_{3}\right)_{2}$ and $[\mathrm{C}]=\mathrm{Th}=\mathrm{NCH}_{3}$, to only $14.7 \mathrm{~kJ} \mathrm{~mol}^{-1}$. Thus, all three model oxo systems have a significant reduction in the energy required to manipulate the $\mathrm{C}-\mathrm{M}-\mathrm{E}$ angle in comparison with the C- and N-based systems.

Electrostatic potential analysis. The above data show that for seven of the nine model complexes examined, the cis geometry is clearly intrinsically favoured, whereas for two of them, namely $[\mathrm{C}]=\mathrm{M}=\mathrm{O}(\mathrm{M}=\mathrm{U}, \mathrm{Ce})$ a trans geometry is preferred. In order to probe and understand why this is the case, we conducted electrostatic potential (ESP) calculations coupled to the commonly employed natural localised molecular orbital (NLMO) approach $^{73}$. Electrostatic potentials allow for the visualisation of the charge distribution of a molecule. ESPs are used extensively to understand complex systems, such as enzymes, but have not hitherto been employed in actinide chemistry outside our previous study ${ }^{64}$.

Previously, we advanced an explanation for the bent structure of $[\mathrm{C}]=\mathrm{U}=\mathrm{NCH}_{3}$ based on the cis-directing nature of the ESP of the $[[\mathrm{C}]=\mathrm{U}]^{2+}$ fragment $^{64}$. The ESP surface around the metal is asymmetric, and favours a negatively charged $\mathrm{E}$ ligand at the cis position. To probe the generality of this effect, we have now conducted analogous calculations on $[[C]=\mathrm{Th}]^{2+}$, and the results are shown in Fig. 5. This shows the evolution of the ESP surface (positive everywhere for a dicationic system) as the [C] ligand is brought up to the Th in $1 \AA$ steps, starting from a point at which the Th- $\mathrm{C}_{[\mathrm{C}]}$ distance is $4 \AA$ longer than in the optimised geometry of $[\mathrm{C}]=\mathrm{Th}=\mathrm{NCH}_{3}$. As with $[[\mathrm{C}]=\mathrm{U}]^{2+}$, at long $r\left(\mathrm{Th}-\mathrm{C}_{[\mathrm{C}]}\right)$ the ESP around the Th is essentially isotropic, but as $r\left(\mathrm{Th}-\mathrm{C}_{[\mathrm{C}]}\right)$ shortens pronounced anisotropic character develops, with the region of positive ESP extending towards the position that the $\mathrm{E}$ ligands occupy in $[\mathrm{C}]=\mathrm{Th}=\mathrm{E}$. Thus, as for $[[\mathrm{C}]=\mathrm{U}]^{2+}$, the interaction of the BIPM model with the Th generates an ESP which is cis-directing towards an incoming negatively charged ligand.

Natural localised molecular orbital analysis. In order to understand the origin of the asymmetric ESP, we analysed the NLMOs of $[[\mathrm{C}]=\mathrm{Th}]^{2+}$ at the equilibrium $r\left(\mathrm{Th}-\mathrm{C}_{[\mathrm{Cl}}\right)$ distance. The NLMO shown in Fig. 6 is highly directional, and would clearly disfavour an incoming negatively charged ligand in the trans position, i.e. there would be substantial repulsion between a ligand approaching from the right hand side of Fig. 6 and the electron in the NLMO shown. This likely accounts for the cisdirecting ESP. The asymmetric ESP of $[[\mathrm{C}]=\mathrm{M}]^{2+}$ nicely explains the small $[\mathrm{C}]-\mathrm{M}-\mathrm{E}$ angles in the majority of the $[\mathrm{C}]=\mathrm{M}=\mathrm{E}$ models studied here. However, the near linearity of $[\mathrm{C}]=\mathrm{Ce}=\mathrm{O}$ and $[\mathrm{C}]=\mathrm{U}=\mathrm{O}$ is not consistent with that observation, which means that there must be another effect at work for those two systems. We therefore conducted an NLMO analysis of all nine $[\mathrm{C}]=\mathrm{M}=\mathrm{E}$ systems, particularly focusing on the $\mathrm{M}=\mathrm{E}$ bonding orbitals. Comparison of these at the optimised geometries with those of the structures at the end of the energy scans reveals that the $\sigma$-orbitals exhibit the greatest energy changes; at least twice those found for the $\pi$-orbitals and more often substantially greater $(\sim \times 20)$. This data can be found in Supplementary Table 3. Additionally, the $\sigma$-orbitals exhibit the greater change in contribution from the metal; on average, these changes are an order of magnitude larger in the $\sigma$ - than the $\pi$-orbitals. Thus, we focus our analysis on the metal-ligand $\sigma$-bonding NLMOs, composition data for which are collected in Table 1, and a representative example of which is shown in Supplementary Figure 15.

For all three $\mathrm{E}$ ligands, the total metal contribution to the $\mathrm{M}-\mathrm{E}$ $\sigma$-bonding NLMO is ordered $\mathrm{Ce} \approx \mathrm{U}>\mathrm{Th}$. This metal contribution is predominantly $\mathrm{d}$-character, except for the $[\mathrm{C}]=\mathrm{Ce}=\mathrm{O}$ and $[\mathrm{C}]=\mathrm{U}=\mathrm{O}$ systems, for which the dominant metal contribution comes from the f-orbitals. Figure 7 plots the total f-contribution 

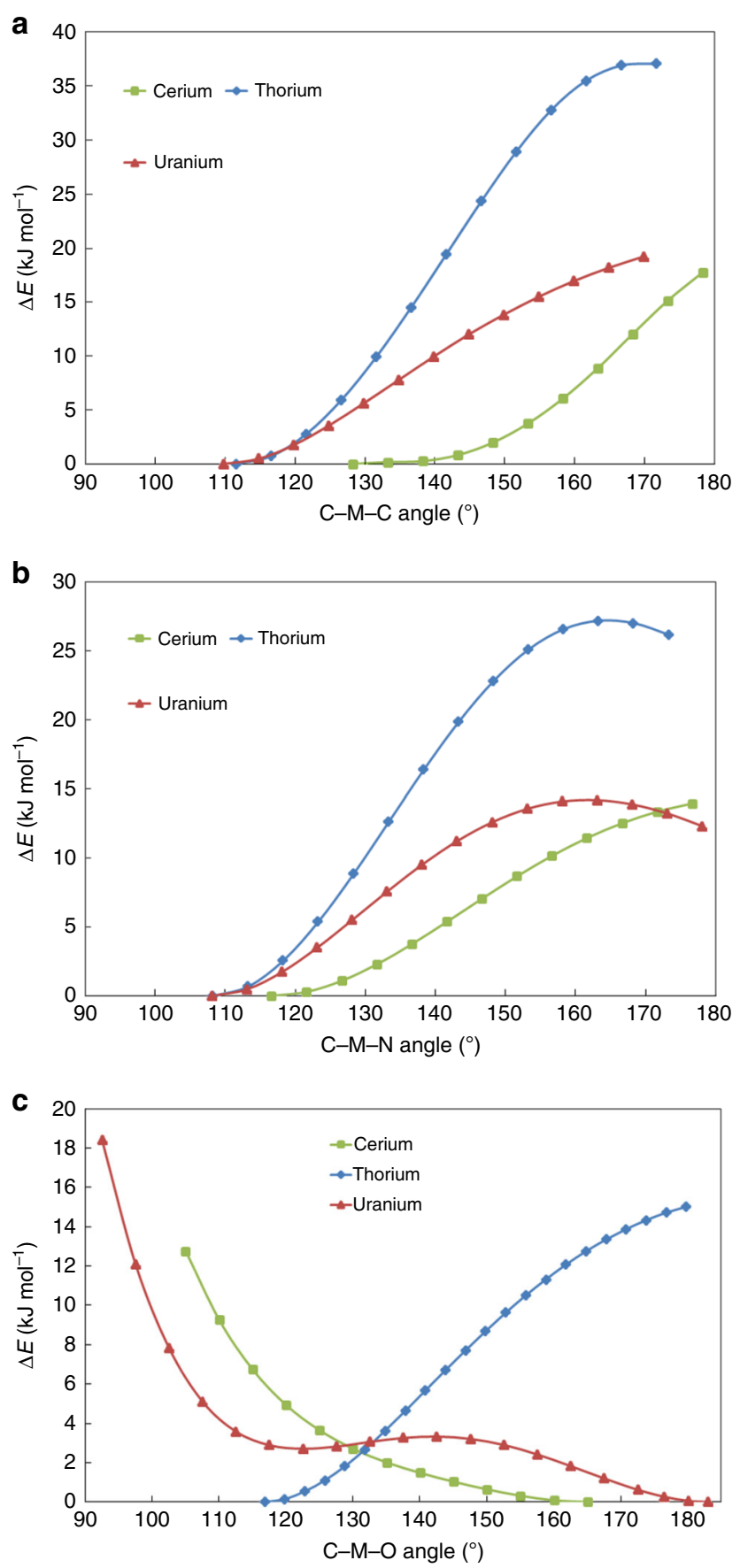

Fig. 4 PBEO SCF energy surface scans of $[C]=M=E$ angles, $M=C e$, Th, $U$. a $\mathrm{E}=\mathrm{C}\left(\mathrm{CH}_{3}\right)_{2}, \mathbf{b} \mathrm{E}=\mathrm{NCH}_{3}, \mathbf{c} \mathrm{E}=\mathrm{O}$. Energies $\left(\mathrm{kJ} \mathrm{mol}{ }^{-1}\right)$ are presented relative to those of the fully optimised structures

to the M-E $\sigma$-bonding NLMO against the $[\mathrm{C}]=\mathrm{M}=\mathrm{E}$ angle for all nine targets; there is a striking correlation, with $R^{2}=0.88$ at the PBE0 level, indicating that the larger the total f-orbital contribution to the $\sigma$-bonding NLMO the larger the $[\mathrm{C}]=\mathrm{M}=\mathrm{E}$ angle, i.e. the $[C]=M=E$ angle is a function of f-orbital based overlap-driven covalency. In contrast, there is very little correlation of the $[\mathrm{C}]=\mathrm{M}=\mathrm{E}$ angle with metal $\mathrm{d}$-character to the NLMO $\sigma$-bonding $\left(R^{2}=0.36\right.$ at the PBE0 level).

If indeed the interaction of the (model) BIPM ligand with the metal centre directs the E ligand into the cis position due to the asymmetric ESP, it would be expected that reducing that interaction by moving the [C] away from the metal would reduce the effect. We therefore moved the model BIPM ligand away from the metal centre by extending the distance between the metal and the central $\mathrm{C}$ atom of $[\mathrm{C}]$ by $1 \AA$, and probed the effect on the energy barrier to alteration of the C-M-E angle. As expected, these barriers are either reduced significantly or removed altogether; the effect on the $[\mathrm{C}]=\mathrm{Th}=\mathrm{C}\left(\mathrm{CH}_{3}\right)_{2}$ system is shown in Supplementary Figure 16. For this molecule, the barrier is reduced by more than half. Extending this argument, elongating the $\mathrm{M}-\mathrm{O}$ distance in either $[\mathrm{C}]=\mathrm{Ce}=\mathrm{O}$ or $[\mathrm{C}]=\mathrm{U}=\mathrm{O}$ should reduce the $\mathrm{M}-\mathrm{O}$ interaction and favour a smaller $\mathrm{C}-\mathrm{M}-\mathrm{O}$ angle. This was probed by lengthening the $\mathrm{Ce}-\mathrm{O}$ distance from its optimised value of 1.77 to $3.0 \AA$, and indeed the preferred $\mathrm{C}$-Ce-O angle decreases from 165 to $135^{\circ}$.

For all seven C-M-E bending TSs located (Supplementary Table 4$)$, there is very little change in $r(\mathrm{M}-\mathrm{E})$, but in all cases bar $[\mathrm{C}]=\mathrm{U}=\mathrm{O}$ there is significant elongation $(>0.08 \AA)$ of $r\left(\mathrm{M}-\mathrm{C}_{[\mathrm{C}]}\right)$ at the TS. This lengthening, and presumably weakening, of the $\mathrm{M}$ $\mathrm{C}_{[\mathrm{C}]}$ interaction destabilises the $\mathrm{TS}$ vs the true minimum geometry. By contrast, the changes in both $r(\mathrm{M}-\mathrm{E})$ and $r$ $\left(\mathrm{M}-\mathrm{C}_{[\mathrm{C}]}\right)$ at the bending $\mathrm{TS}$ located for $[\mathrm{C}]=\mathrm{U}=\mathrm{O}$ are very modest, in agreement with this TS being of much lower relative energy than the other six. Indeed, the energy surfaces presented in Fig. $4 \mathrm{a}-\mathrm{c}$ suggest that the TS for $[\mathrm{C}]=\mathrm{U}=\mathrm{O}$ could be considered separately from the rest.

The classic trans influence in transition metal element chemistry arises from the competition for metal d-orbitals between two mutually trans ligands, resulting in the elongation of the bond trans to the stronger donor ligand. If this were a key factor in our systems, we would expect the lengthening of $r$ $\left(\mathrm{M}-\mathrm{C}_{[\mathrm{C}]}\right)$ to be related to the d-orbital content of the M-E NLMO at the TS. However, we find essentially no such correlation between these variables; $R^{2}=0.20$ for the correlation of the total metal d-orbital contribution to the TS' M-E $\sigma$ NLMO with the $r$ $\left(\mathrm{M}-\mathrm{C}_{[\mathrm{C}]}\right.$ ) elongation (in the six TSs bar that in $\left.[\mathrm{C}]=\mathrm{U}=\mathrm{O}\right)$. An alternative explanation for the $r\left(\mathrm{M}-\mathrm{C}_{[\mathrm{C}]}\right)$ elongation is an extension of the electrostatic argument presented above; rotating the E ligands away from the optimised C-M-E angles and towards linearity moves them from the orientation favoured by the asymmetric ESP surface around the metal, and the system adjusts by attempting to reduce the asymmetric ESP by elongating $r(\mathrm{M}-$ $\mathrm{C}_{[\mathrm{C}]}$ ).

GGA-type DFAs typically favour greater electron delocalisation, leading to more radially diffuse orbitals. It is interesting to note that for almost all of the complexes studied here the GGAtype functional, $\mathrm{PBE}$, produces $\sigma$-bonding NLMOs with greater $\mathrm{f}$ orbital character (Table 1). The only exception is $[\mathrm{C}]=\mathrm{U}=\mathrm{NCH}_{3}$, which shows a significant increase in $s$ orbital contribution. However, it is important to note that the differences between PBE and PBE0 are slight, and a consistent trend emerges whereby the f-orbital contribution is, like-for-like, always greater than the $d$ orbital contribution for $\mathrm{Ce}$ and $\mathrm{U}$ compared to Th. This is the case irrespective of the identity of E, but is certainly most pronounced for the oxo complexes, giving confidence that the high f-orbital contributions to the $\mathrm{Ce}=\mathrm{O}$ and $\mathrm{U}=\mathrm{O}$ bonds are real and not a computational artefact.

Topological bonding analysis. To further investigate the bonding between the metal centre and E ligand, analysis of the topology of the electron density was carried out with the Quantum Theory of Atoms in Molecules (QTAIM) ${ }^{74,75}$. We focus on three parameters; the electron density at the bond critical point (BCP) along the bond path between the $\mathrm{M}$ and $\mathrm{C} / \mathrm{N} / \mathrm{O}$ atomic centres $\left(\rho_{\mathrm{BCP}}\right)$, the total energy density at the $\mathrm{BCP}\left(H_{\mathrm{BCP}}\right)$ and the delocalisation index between the $\mathrm{M}$ and $\mathrm{C} / \mathrm{N} / \mathrm{O}$ atomic basins $\delta$ $(\mathrm{M}, \mathrm{E})$. The magnitudes of these parameters, in an absolute sense, 

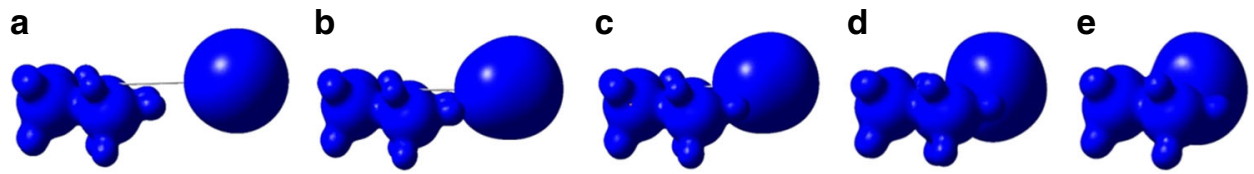

Fig. 5 Electrostatic potential (ESP) surface of the $[C]=T h^{2+}$ fragment. As a function of distance this shows the approach of the model BIPM [C] ligand to the Th $\left[r\left(T h-C_{[C]}\right)\right]$ at a $6.491 \AA, \mathbf{b} 5.491 \AA, \mathbf{c} 4.491 \AA, \mathbf{d} 3.491 \AA$, e $2.491 \AA$, the value in the optimised structure of $[C]=T h=N C H$. The isovalue is 0.5

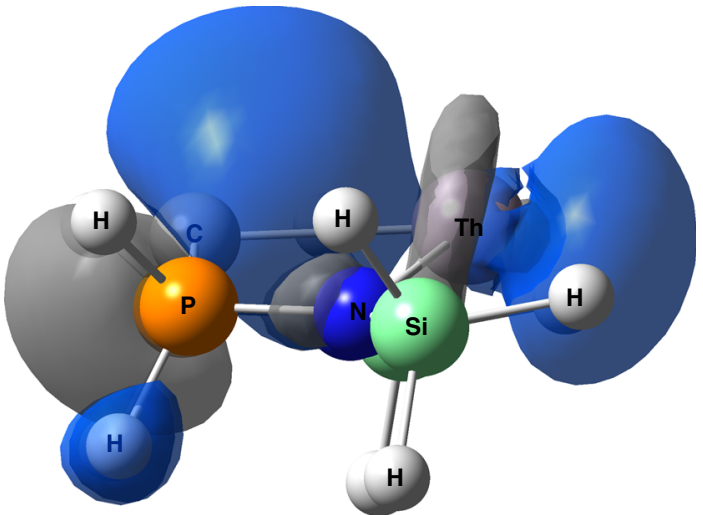

Fig. $6 \mathrm{NLMO}$ of $[\mathrm{C}]=\mathrm{Th}^{2+}$. This NLMO has significant amplitude in the trans direction, resulting in a cis directing effect. The orbital is $16.86 \%$ Th character, and that component is composed of $19.77 \% 7 \mathrm{~s}, 63.88 \% 6 \mathrm{~d}$, and $16.05 \% 5 f$

provide a measure of the overall extent of covalency in the bonding interactions. The data for the nine model complexes are summarised in Table 2, and reveal some clear trends. For a given metal, all three metrics increase (in an absolute sense) in the order $\mathrm{C}\left(\mathrm{CH}_{3}\right)_{2}<\mathrm{NCH}_{3}<\mathrm{O}$ while, for a given E ligand, the QTAIM metrics increase in the order $\mathrm{Th}<\mathrm{U}<\mathrm{Ce}$. The data indicate that $[\mathrm{C}]=\mathrm{Ce}=\mathrm{O}$ and $[\mathrm{C}]=\mathrm{U}=\mathrm{O}$ have the most covalent $\mathrm{M}-\mathrm{E}$ interactions, in agreement with the suggestion that the cisdirecting ESP is overcome only in the most covalent of our systems.

The QTAIM metrics give us a measure of overall covalency, whereas NLMO analysis allows us to assess specific orbitals. Together they provide complementary methods to assess covalency and, ideally, we expect correlations between the data from the two techniques. This is assessed in Table 3, where the regression analyses for the correlation of a number of key variables are presented. In all bar three cases, the $R^{2}$ values are well over 0.9 , indicating strong correlations between the NLMO and QTAIM metrics. This is particularly so for $\rho_{\mathrm{BCP}}$. That both orbital and electron density-based assessments of covalency correlate so well gives confidence in our conclusions regarding the extent of covalency in these An-E interactions.

\section{Discussion}

Noting the orbital and parity arguments for the ITI presented above, we recognise that either of these logical, but largely speculative, arguments can be combined and subsumed into the ESP argument based on the calculation on the electronic structure of $[[\mathrm{C}]=\mathrm{M}]^{2+}$. It is clear from the computed data that the thorium complexes have much the strongest preference for a cis geometry. At first, if considering orbital arguments, this is counterintuitive because the bonding of thorium is more ionic than uranium and so orbital factors, and thus the cis effect, should be diminished.
However, when an ESP argument is considered, the stronger preference of thorium to adopt a cis geometry falls entirely into line with what would be predicted based on where the charge build-up occurs, i.e. trans, thus leaving a cis hole to accommodate a cis ligand. This might be linked to thorium d-orbital character, however although the computed data in Table 1 superficially supports this, more detailed assessment shows that this is not the case. This leads us to an important conclusion, which is that in the absence of other drivers it is the ESP that dominates the resulting geometry; this is not contingent on the d-orbital character in the M-E bond, but this does not mean that d-orbitals may not be used as a consequence. So, d-orbital character may result from the cis geometry but the cis geometry does not itself result from d-orbital character. This ESP argument thus extends and refines Denning's original proposition ${ }^{45,46}$ into a more quantified, and firmer, basis.

Having established that the preferred geometry of the complexes in this study is cis, we now address why $[\mathrm{C}]=\mathrm{U}=\mathrm{O}$ and $[\mathrm{C}]=\mathrm{Ce}=\mathrm{O}$ prefer trans geometries. We propose that the optimised $[\mathrm{C}]=\mathrm{M}=\mathrm{E}$ angles arise from the interplay of electrostatic (ionic) and orbital (covalent) effects; the former favour the cis orientation while the latter favour linearity. It is likely that the orbital effects dominate in $[\mathrm{C}]=\mathrm{Ce}=\mathrm{O}$ and $[\mathrm{C}]=\mathrm{U}=\mathrm{O}$ because of the small size of $\mathrm{O}^{2-}$; these two systems have the shortest $\mathrm{M}-\mathrm{E}$ distances (Supplementary Table 4 ) and hence only in $[\mathrm{C}]=\mathrm{Ce}=\mathrm{O}$ and $[\mathrm{C}]=\mathrm{U}=\mathrm{O}$ is the $\mathrm{M}-\mathrm{E}$ distance short enough to allow sufficient f-orbital/ligand overlap for the covalent driver to linearity to overcome the cis-directing ionic effect. Certainly, f-character dominates the M-E $\sigma$-bonding NLMOs of $[\mathrm{C}]=\mathrm{U}=\mathrm{O}$ and $[C]=\mathrm{Ce}=\mathrm{O}$ in contrast to the other seven model systems where $\mathrm{d}$-character dominates, Table 1 . Looking more widely, it is certainly the case that where the ITI clearly occurs or is proposed to occur this almost always involves small, highly charged ligands such as $\mathrm{N}^{3-}$ and $\mathrm{O}^{2-}$ with short $\mathrm{M}-\mathrm{E}$ distances ${ }^{43,51-57}$. In other words, given the radially contracted nature of $5 \mathrm{f}$ orbitals compared to $6 \mathrm{~d}$, only at short $\mathrm{M}-\mathrm{E}$ distances can the 5 f-orbitals come into the bonding picture and exert their influence to favour a trans $[\mathrm{C}]=\mathrm{M}=\mathrm{O}$ geometry. As we noted earlier, the oxo systems require significantly smaller energies to manipulate the $\mathrm{C}-\mathrm{M}-\mathrm{E}$ angle in comparison with the $\mathrm{C}$ - and $\mathrm{N}$-based systems, and we suggest that this is because the ionic and covalent effects are most finely balanced in these molecules. For $\mathrm{E}=\mathrm{C}\left(\mathrm{CH}_{3}\right)_{2}$ and $\mathrm{NCH}_{3}$, Th has much the strongest preference for the cis geometry, and $[\mathrm{C}]=\mathrm{Th}=\mathrm{O}$ is the only oxo to favour significantly bent $\mathrm{C}-\mathrm{Th}-\mathrm{O}$. For a given $\mathrm{E}$ ligand, the Th compound has the lowest $\mathrm{f}$ contribution to the M-E $\sigma$-bonding NLMO, and the QTAIM metrics are the smallest. Hence the Th-E interaction is clearly the most ionic and its geometry is dominated by electrostatics. By contrast, for $[\mathrm{C}]=\mathrm{M}=\mathrm{O}(\mathrm{M}=\mathrm{Ce}, \mathrm{U}) \mathrm{f}$-orbital covalency plays a structuredictating role, something normally (i.e. in the FEUDAL model) limited to d-orbitals. Indeed, even for lanthanides TI effects have been convincingly attributed to the role of $\mathrm{d}-$, not $\mathrm{f}-$, orbitals in bonding to ligands ${ }^{27,31}$. We therefore suggest that, within the interplay of early actinide ionic vs covalent effects, the structuredirecting capacity of overlap-driven covalency is not solely the domain of the d-orbitals. 


\begin{tabular}{|c|c|c|c|c|c|c|c|c|c|}
\hline \multirow[t]{2}{*}{$\mathbf{E}$} & \multirow[t]{2}{*}{$\mathbf{M}$} & \multirow[t]{2}{*}{ Functional } & \multicolumn{5}{|c|}{ Contribution of $M$ to the $\sigma$-bonding NLMO } & \multirow[t]{2}{*}{ Total d } & \multirow[t]{2}{*}{ Total $\mathrm{f}$} \\
\hline & & & $\mathbf{M}$ & s & $\mathbf{p}$ & d & $\mathbf{f}$ & & \\
\hline \multirow[t]{4}{*}{$\mathrm{C}\left(\mathrm{CH}_{3}\right)_{2}$} & \multirow[t]{2}{*}{$\mathrm{Ce}$} & PBEO & 31.19 & 1.48 & 0.09 & 63.74 & 34.66 & 19.88 & 10.81 \\
\hline & & PBE & 30.41 & 2.84 & 0.09 & 60.05 & 37.00 & 18.26 & 11.25 \\
\hline & \multirow[t]{2}{*}{$U$} & PBEO & 28.89 & 8.32 & 0.24 & 61.19 & 30.25 & 17.68 & 8.74 \\
\hline & & PBE & 30.56 & 10.59 & 0.21 & 56.83 & 32.36 & 17.37 & 9.89 \\
\hline \multirow[t]{5}{*}{$\mathrm{NCH}_{3}$} & \multirow[t]{2}{*}{$\mathrm{Ce}$} & PBEO & 19.58 & 3.75 & 0.14 & 69.97 & 26.13 & 13.70 & 5.12 \\
\hline & & PBE & 18.61 & 4.65 & 0.17 & 67.37 & 27.80 & 12.54 & 5.17 \\
\hline & \multirow[t]{2}{*}{ Th } & PBEO & 15.36 & 6.57 & 0.95 & 75.09 & 17.35 & 11.53 & 2.66 \\
\hline & & PBE & 15.86 & 7.13 & 1.07 & 73.30 & 18.48 & 11.63 & 2.93 \\
\hline & $U$ & PBEO & 19.18 & 7.91 & 0.28 & 60.01 & 31.77 & 11.51 & 6.09 \\
\hline \multirow{3}{*}{$\mathrm{O}$} & Th & PBE & 16.80 & 1.73 & 5.32 & 56.38 & 36.49 & 9.47 & 6.13 \\
\hline & \multirow[t]{2}{*}{ U } & PBEO & 24.20 & 1.73 & 0.59 & 22.84 & 74.79 & 5.53 & 18.10 \\
\hline & & PBE & 23.94 & 1.42 & 0.58 & 22.44 & 75.52 & 5.37 & 18.08 \\
\hline
\end{tabular}

aThe total $d$ and total $f$ values are the products of the metal contribution and its $d$ and $f$ breakdowns

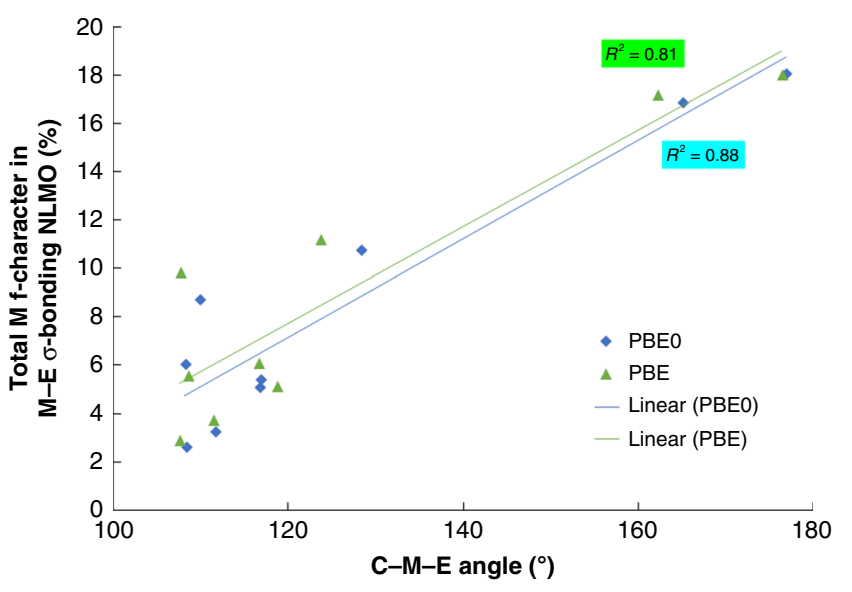

Fig. 7 The $C-M-E$ angle $\left(^{\circ}\right)$ vs the total metal $f$ character in the $M-E \sigma$ bonding NLMO (\%) of $[\mathrm{C}]=\mathrm{M}=\mathrm{E} . \mathrm{C}=\mathrm{C}\left(\mathrm{PH}_{2} \mathrm{NSiH}_{3}\right)_{2} ; \mathrm{M}=\mathrm{Ce}$, Th, $\mathrm{U} ; \mathrm{E}=\mathrm{C}$ $\left.\left(\mathrm{CH}_{3}\right)_{2}, \mathrm{NCH}_{3}, \mathrm{O}\right) . R^{2}$ with PBEO (PBE) for $\mathrm{Ce}$, Th, and $\mathrm{U}$ are $0.93(0.83)$, 0.97 (0.96), and $0.96(0.88)$, respectively

To summarise, we have prepared thorium-carbene-imido complexes, which together with uranium analogues has enabled us to conduct an experimentally grounded computational study into TI and ITI effects in carbene-carbene, carbene-imido, and carbene-oxo ligand combinations at uranium, thorium, and cerium. By conducting calculations on models freed from steric and counter-ion constraints, we have been able to place the ITI on a quantified, firmer footing. We find that a strong donor ligand such as the carbene generates an ESP that is inherently cisdirecting in terms of subsequent ligand coordination. This reveals that d-orbital participation in the M-E bonds may opportunistically result from this ESP but does not drive it. When f-orbital participation, with associated overlap-driven covalency, becomes dominant via short $\mathrm{M}-\mathrm{E}$ distances then this ionic effect is overcome and a trans geometry is favoured. This study therefore contradicts the previous assessment of the ITI as resulting from

\begin{tabular}{|c|c|c|c|c|}
\hline $\mathbf{E}$ & $\mathbf{M}$ & $\rho_{\mathrm{BCP}}$ & $H_{\mathrm{BCP}}$ & $\delta(\mathrm{M}, \mathrm{E})$ \\
\hline \multirow{3}{*}{$\mathrm{C}\left(\mathrm{CH}_{3}\right)_{2}$} & $\mathrm{Ce}$ & 0.166 & -0.093 & 1.56 \\
\hline & Th & 0.146 & -0.078 & 1.39 \\
\hline & U & 0.156 & -0.082 & 1.48 \\
\hline \multirow[t]{3}{*}{$\mathrm{NCH}_{3}$} & $\mathrm{Ce}$ & 0.195 & -0.123 & 1.89 \\
\hline & Th & 0.178 & -0.110 & 1.63 \\
\hline & $U$ & 0.197 & -0.125 & 1.80 \\
\hline \multirow[t]{3}{*}{$\mathrm{O}$} & $\mathrm{Ce}$ & 0.284 & -0.247 & 1.91 \\
\hline & Th & 0.242 & -0.202 & 1.68 \\
\hline & $U$ & 0.278 & -0.242 & 1.87 \\
\hline
\end{tabular}

synergistic interplay of ionic and covalent effects in that here the data suggest that they work against each other in cases where the structure-directing role of f-orbitals is confirmed. This work therefore also suggests an instance where FEUDAL breaks down. The structure-directing capacity of overlap-driven covalency would therefore seem to be not solely the domain of the $\mathrm{d}$ orbitals; here the suggestion of the structure-directing role of $f$ orbital overlap-driven covalency emerges.

\section{Methods}

Preparation of $\left[\mathrm{Th}\left\{\mathrm{C}\left(\mathrm{PPh}_{2} \mathrm{NSiMe}_{3}\right)_{2}\right\}\left(\mathrm{NHCPh}_{3}\right)_{2}\right]$ (4). At $-78^{\circ} \mathrm{C}$, a solution of $\mathrm{Ph}_{3} \mathrm{CNH}_{2}(0.830 \mathrm{~g}, 3.2 \mathrm{mmol})$ in toluene $(10 \mathrm{ml})$ was added to a stirring solution of $3(1.926 \mathrm{~g}, 2 \mathrm{mmol})$ in toluene $(10 \mathrm{ml})$. The mixture was allowed to stir at $-78^{\circ} \mathrm{C}$ for $30 \mathrm{~min}$ and at ambient temperature for $3 \mathrm{~h}$. After which, the mixture was filtered, and all volatiles in the filtrate were evaporated under vacuum to afford a viscous yellow oil. The oil was washed with pentane $(5 \mathrm{ml} \times 4)$ and dried under vacuum to afford 4 as a yellow solid. Yield: $1.400 \mathrm{~g}, 54 \%$. Single crystals suitable for $\mathrm{X}$-ray diffraction were obtained from toluene solution at $0^{\circ} \mathrm{C}$. Anal. Calcd for $\mathrm{C}_{69} \mathrm{H}_{70} \mathrm{~N}_{4} \mathrm{P}_{2} \mathrm{Si}_{2} \mathrm{Th} \cdot 0.5\left(\mathrm{C}_{7} \mathrm{H}_{8}\right)$ : C, 64.43; H, 5.52; N, 4.15. Found: C, 63.64; H, 5.60; N, 3.64. ${ }^{1} \mathrm{H}$ NMR $\left(\mathrm{C}_{6} \mathrm{D}_{6}, 298 \mathrm{~K}\right): \delta(\mathrm{ppm}) 0.01\left(\mathrm{~s}, 18 \mathrm{H},-\mathrm{SiMe}_{3}\right), 4.03(\mathrm{~s}, 2 \mathrm{H}$,

- $\left.\mathrm{NHCPh}_{3}\right), 6.95-6.99(\mathrm{~m}, 9 \mathrm{H}, \mathrm{ArH}), 7.02-7.08(\mathrm{~m}, 13 \mathrm{H}, \mathrm{ArH}), 7.18-7.20(\mathrm{~m}, 9 \mathrm{H}$ 


\begin{tabular}{|c|c|c|c|c|}
\hline \multirow[t]{2}{*}{ Variables } & & \multicolumn{3}{|l|}{$R^{2}$} \\
\hline & & $\mathrm{C}\left(\mathrm{CH}_{3}\right)_{2}$ & $\mathbf{N C H}_{3}$ & 0 \\
\hline $\begin{array}{l}\text { Total M character in } \sigma \\
\text { bonding M-E NLMO } \\
(\%) \\
\text { Total M f orbital } \\
\text { character in } \sigma \text { bonding } \\
\text { M-E NLMO (\%) }\end{array}$ & $\begin{array}{l}\text { vs } \rho_{\mathrm{BCP}} \\
\text { vs } H_{\mathrm{BCP}} \\
\text { vs } \delta(\mathrm{M}, \mathrm{E}) \\
\text { vs } \rho_{\mathrm{BCP}} \\
\text { vs } H_{\mathrm{BCP}} \\
\text { vs } \delta(\mathrm{M}, \mathrm{E})\end{array}$ & $\begin{array}{l}0.941 \\
0.773 \\
0.956 \\
0.937 \\
0.766 \\
0.953\end{array}$ & $\begin{array}{l}0.967 \\
0.956 \\
0.933 \\
0.967 \\
0.976 \\
0.657\end{array}$ & $\begin{array}{l}0.950 \\
0.943 \\
0.918 \\
0.953 \\
0.965 \\
0.939\end{array}$ \\
\hline
\end{tabular}

${ }^{\mathrm{a}} \rho_{\mathrm{BCP}}$ is the bond critical point between the $\mathrm{M}$ and $\mathrm{C} / \mathrm{N} / \mathrm{O}$ centres, $H_{\mathrm{BCP}}$ is the total energy $\rho_{\mathrm{BCP}}$ is the bond critical point between $\mathrm{N} / \mathrm{O}$ atomic basins
ArH), 7.54-7.59 (m, 19 H, ArH). ${ }^{31} \mathrm{P}$ NMR $\left(\mathrm{C}_{6} \mathrm{D}_{6}, 298 \mathrm{~K}\right): \delta(\mathrm{ppm}) 4.70$ (s). ${ }^{13} \mathrm{C}$ $\left\{{ }^{1} \mathrm{H}\right\} \operatorname{NMR}\left(\mathrm{C}_{6} \mathrm{D}_{6}, 298 \mathrm{~K}\right): \delta(\mathrm{ppm}) 3.91\left(\mathrm{~s},-\mathrm{SiMe}_{3}\right), 77.81\left(\mathrm{~s},-\mathrm{NHCPh}_{3}\right), 126.90$, $128.78,129.00,129.46,130.10(\mathrm{ArC}), 131.69\left(\mathrm{t},{ }^{2} J_{\mathrm{PC}}=5.0 \mathrm{~Hz}, \mathrm{C}_{\text {meta }}\right.$ of $\left.\mathrm{P}-\mathrm{Ph}\right)$, $139.72\left(\mathrm{t},{ }^{1} J_{\mathrm{PC}}=49.1 \mathrm{~Hz}, \mathrm{C}_{\mathrm{ipso}}\right.$ of P-Ph), $152.20(\mathrm{ArC})$. ATR-IR $v \mathrm{~cm}^{-1}: 3052(\mathrm{w})$, $3019(\mathrm{w}), 2947(\mathrm{w}), 2892(\mathrm{w}), 1594(\mathrm{w}), 1488(\mathrm{~m}), 1435(\mathrm{~s}), 1346(\mathrm{~s}), 1282(\mathrm{~s}), 1246$ $(\mathrm{m}), 1177(\mathrm{~s}), 1149(\mathrm{~m}), 1105(\mathrm{~m}), 1080(\mathrm{~s}), 1043(\mathrm{~m}), 1024(\mathrm{~s}), 831(\mathrm{~m}), 764(\mathrm{~m})$, $695(\mathrm{~s}), 637(\mathrm{~s}), 603(\mathrm{~m}), 545(\mathrm{~m}), 526(\mathrm{~s}), 509(\mathrm{~s}), 471(\mathrm{~s}), 457(\mathrm{~s}), 410(\mathrm{~s})$.

\section{Preparation of $\left[\mathrm{Th}\left\{\mathrm{C}\left(\mathrm{PPh}_{2} \mathrm{NSIMe}_{3}\right)_{2}\right\}\left(=\mathrm{NCPh}_{3}\right)\left(-\mathrm{NHCPh}_{3}\right)(\mathrm{K})\right](2 \mathrm{ThNHRK})$}

At ambient temperature, $15 \mathrm{ml}$ of benzene was added to a stirring solid mixture of $4(652.3 \mathrm{mg}, 0.5 \mathrm{mmol})$ and $\mathrm{KBn}(136.7 \mathrm{mg}, 1.05 \mathrm{mmol})$ to afford a brick red suspension. The mixture was stirred at ambient temperature for $3 \mathrm{~h}$ and filtered. All volatiles were removed from the red solution, the red residue was washed with pentane $(5 \mathrm{ml} \times 5)$ and dried in vacuo to afford 2 ThNHRK as a red solid $(385.2 \mathrm{mg}$, $57 \%)$. Single crystals suitable for X-ray diffraction were obtained from benzene solution under ambient temperature. Once obtained as crystalline material, 2ThNHRK is not soluble in aromatic and aliphatic solvents, and decomposes in coordinative and polar solvents. So, the ${ }^{1} \mathrm{H}$ and ${ }^{31} \mathrm{P}$ NMR spectra were recorded from the NMR scale reaction. However, satisfactory ${ }^{13} \mathrm{C}$ and ${ }^{29} \mathrm{Si}$ NMR spectra could not be obtained. The electronic absorption spectrum is also not available for the same reason. Anal. Calcd for $\mathrm{C}_{69} \mathrm{H}_{69} \mathrm{KN}_{4} \mathrm{P}_{2} \mathrm{Si}_{2}$ Th: $\mathrm{C}, 61.68 ; \mathrm{H}, 5.18 ; \mathrm{N}, 4.17$. Found: C, 59.94; H, 5.25; N, 3.85. ${ }^{1} \mathrm{H}$ NMR $\left(\mathrm{C}_{6} \mathrm{D}_{6}, 298 \mathrm{~K}\right): \delta(\mathrm{ppm}) 0.11(\mathrm{~s}, 18 \mathrm{H}$, $-\mathrm{SiMe}$ ), $3.93\left(\mathrm{~s}, 1 \mathrm{H},-\mathrm{NHCPh}_{3}\right), 6.89-7.07(\mathrm{~m}, 22 \mathrm{H}, \mathrm{ArH}), 7.20-7.25(\mathrm{~m}, 14 \mathrm{H}$, $\operatorname{Ar} H)$, 7.56-7.58 (m, $6 \mathrm{H}, \mathrm{ArH}), 7.88-7.90(\mathrm{~m}, 6 \mathrm{H}, \mathrm{ArH}) .{ }^{31} \mathrm{P}$ NMR $\left(\mathrm{C}_{6} \mathrm{D}_{6}, 298 \mathrm{~K}\right)$ : $\delta(\mathrm{ppm})-2.24(\mathrm{~s})$. ATR-IR $v \mathrm{~cm}^{-1}: 3053(\mathrm{w}), 3020(\mathrm{w}), 2946(\mathrm{w}), 2893(\mathrm{w}), 1592$ (w), $1483(\mathrm{~m}), 1434(\mathrm{~s}), 1352(\mathrm{w}), 1244(\mathrm{~s}), 1103(\mathrm{~s}), 1058(\mathrm{~s}), 1025(\mathrm{~s}), 893(\mathrm{~s}), 828$ $(\mathrm{s}), 749(\mathrm{~s}), 697(\mathrm{~s}), 633(\mathrm{~m}), 594(\mathrm{~m}), 546(\mathrm{~m}), 523(\mathrm{~s}), 510(\mathrm{~m}), 480(\mathrm{~s}), 414(\mathrm{~m})$.

\section{Preparation of $\left[\mathrm{Th}\left\{\mathrm{C}\left(\mathrm{PPh}_{2} \mathrm{NSiMe}_{3}\right)_{2}\right\}\left(=\mathrm{NCPh}_{3}\right)\left(\kappa^{2}-\mathrm{N}, \mathrm{N}^{\prime}-2,2\right.\right.$-bipyridine $\left.)\right]$ (2ThBIPY). At $-78^{\circ} \mathrm{C}$, a solution of $2,2^{\prime}$-BIPY $(0.555 \mathrm{~g}, 3.55 \mathrm{mmol})$ and} $\mathrm{Ph}_{3} \mathrm{CNH}_{2}(0.922 \mathrm{~g}, 3.55 \mathrm{mmol})$ in toluene $(20 \mathrm{ml})$ was added into a stirring toluene solution of $3(5.705 \mathrm{~g}, 5.93 \mathrm{mmol}, 30 \mathrm{ml})$ in a dropwise manner. The addition was completed in $1 \mathrm{~h}$. The red solution was allowed to gradually warm to ambient temperature and stirred at ambient temperature for $12 \mathrm{~h}$ then filtered. The deep red filtrate was concentrated to approximate $5 \mathrm{ml}$ and stored at $-35^{\circ} \mathrm{C}$ overnight, affording 2ThBIPY as a red crystalline solid $(2.487 \mathrm{~g}, 54 \%)$. Anal. Calcd for $\mathrm{C}_{60} \mathrm{H}_{61} \mathrm{~N}_{5} \mathrm{P}_{2} \mathrm{Si}_{2}$ Th: C, 59.94; H, 5.11; N, 5.82. Found: C, 60.29; H, 5.02; N, 5.45. ${ }^{1} \mathrm{H}$ NMR $\left(\mathrm{C}_{6} \mathrm{D}_{6}, 298 \mathrm{~K}\right): \delta(\mathrm{ppm})-0.04\left(\mathrm{~s}, 18 \mathrm{H},-\mathrm{SiMe} e_{3}\right), 6.87-6.91(\mathrm{~m}, 2 \mathrm{H}, \mathrm{ArH})$, 6.93-6.98 (m, 6 H, ArH), 7.02-7.15 (m, 9 H, ArH), 7.20-7.29 (m, 12 H, ArH), 7.40-7.44 (m, $4 \mathrm{H}$, Pyridine- $H$ ), 8.19-8.21 (m, $6 \mathrm{H}, \mathrm{Ar} H), 8.23-8.28(\mathrm{~m}, 4 \mathrm{H}$, Pyridine- $H) .{ }^{31} \mathrm{P}$ NMR $\left(\mathrm{C}_{6} \mathrm{D}_{6}, 298 \mathrm{~K}\right): \delta(\mathrm{ppm})-1.26(\mathrm{~s}) .{ }^{13} \mathrm{C}\left\{{ }^{1} \mathrm{H}\right\}$ NMR $\left(\mathrm{C}_{6} \mathrm{D}_{6}\right.$, $\left.298 \mathrm{~K}): \delta(\mathrm{ppm}) 3.29(-\mathrm{SiMe})_{3}\right), 21.77\left(\mathrm{Th}=\mathrm{N}-\mathrm{CPh}_{3}\right), 121.70,124.64,126.03$, $127.46,128.90,129.45,129.67,130.61(\mathrm{ArC}), 131.91\left(\mathrm{t},{ }^{2} J_{\mathrm{PC}}=6.0 \mathrm{~Hz}, \mathrm{C}_{\text {meta }}\right.$ of $\mathrm{P}-\mathrm{Ph}), 132.15\left(\mathrm{t},{ }^{2} J_{\mathrm{PC}}=6.0 \mathrm{~Hz}, \mathrm{C}_{\mathrm{meta}}\right.$ of $\left.\mathrm{P}-\mathrm{Ph}\right), 138.22,139.63,152.20,154.33$, 156.45 (Pyridine-C). ATR-IR $v \mathrm{~cm}^{-1}: 3055(\mathrm{w}), 2941$ (w), $2894(\mathrm{w}), 1591(\mathrm{~m})$, $1572(\mathrm{w}), 1478(\mathrm{~m}), 1434(\mathrm{~s}), 1309(\mathrm{~s}), 1242(\mathrm{~s}), 1113(\mathrm{~s}), 1054(\mathrm{~s}), 827(\mathrm{~s}), 763(\mathrm{~s})$, $743(\mathrm{~m}), 696(\mathrm{~s}), 677(\mathrm{~s}), 629(\mathrm{~s}), 591(\mathrm{~s}), 538(\mathrm{~s}), 513(\mathrm{~s}), 421(\mathrm{~s})$.

Preparation of $\left[\mathrm{Th}\left(\mathrm{BIPM}{ }^{\mathrm{TMS}}\right)\left(\mathrm{NHCPh}_{3}\right)\left(\mathrm{CH}_{2} \mathrm{SiMe}_{3}\right)\right]$ (5). At $-78^{\circ} \mathrm{C}$ a solution of $\mathrm{Ph}_{3} \mathrm{CNH}_{2}(136 \mathrm{mg}, 0.9 \mathrm{mmol})$ in toluene $(10 \mathrm{ml})$ was added slowly into a stirring solution of $3(963.2 \mathrm{mg}, 1 \mathrm{mmol})$ in toluene $(10 \mathrm{ml})$. The mixture was stirred at $-78^{\circ} \mathrm{C}$ for $15 \mathrm{~min}$, then at ambient temperature for $1 \mathrm{~h}$. The mixture was then filtered, and all volatiles in the yellow filtrate were evaporated under vacuum to afford $\mathbf{5}$ as a yellow solid. Yield: $0.79 \mathrm{~g}, 95 \%$. Complex $\mathbf{5}$ is a thermally unstable complex, decomposing in the solid state in a few days at $-35^{\circ} \mathrm{C}$, or in a few hours in $\mathrm{C}_{6} \mathrm{D}_{6}$ solution at room temperature. Thus reliable microanalyses result, optical, IR, and ${ }^{13} \mathrm{C} /{ }^{29} \mathrm{Si} N \mathrm{NR}$ data are not available. ${ }^{1} \mathrm{H}$ NMR $\left(\mathrm{C}_{6} \mathrm{D}_{6}, 298 \mathrm{~K}\right): \delta(\mathrm{ppm})$
-0.06 (s, $2 \mathrm{H},-\mathrm{CH}_{2} \mathrm{SiMe}_{3}$ ), 0.04 (s, $18 \mathrm{H}, \mathrm{NSi} M e_{3}$ ), 0.49 (s, $9 \mathrm{H} .-\mathrm{CH}_{2} \mathrm{Si}_{3} e_{3}$ ), 4.35 (s, $1 \mathrm{H},-\mathrm{NHCPh}$ ), 6.88-6.93 (m, 6 H, ArH), 7.20-7.26 (m, 9 H, ArH), 7.52-7.55 (m, $9 \mathrm{H}, \mathrm{ArH}), 7.70-7.81(\mathrm{~m}, 6 \mathrm{H}, \mathrm{Ar} H) .{ }^{31} \mathrm{P} \mathrm{NMR}\left(\mathrm{C}_{6} \mathrm{D}_{6}, 298 \mathrm{~K}\right): \delta(\mathrm{ppm}) 5.49(\mathrm{~s})$

\section{Data availability}

The X-ray crystallographic coordinates for structures reported in this Article have been deposited at the Cambridge Crystallographic Data Centre (CCDC), under deposition nos. 1861112-1861114. These data can be obtained free of charge from The Cambridge Crystallographic Data Centre (www.ccdc.cam.ac.uk/data_request/cif). All other data can be obtained from the authors on request.

Received: 13 September 2018 Accepted: 15 January 2019 Published online: 07 February 2019

\section{References}

1. Ephritikhine, M. The vitality of uranium molecular chemistry at the dawn of the XXIst century. Dalton Trans. 2501-2516 (2006)

2. Kozimor, S. A. et al. Trends in covalency for $\mathrm{d}$ - and f-element metallocene dichlorides identified using chlorine K-edge X-ray absorption spectroscopy and time-dependent density functional theory. J. Am. Chem. Soc. 131, 12125-12136 (2009).

3. Hayton, T. W. Metal-ligand multiple bonding in uranium: structure and reactivity. Dalton. Trans. 39, 1145-1158 (2010).

4. Seaman, L. A. et al. Probing the $5 \mathrm{f}$ orbital contribution to the bonding in a U(V) ketimide complex. J. Am. Chem. Soc. 134, 4931-4940 (2012).

5. Minasian, $\mathrm{S}$. G. et al. Determining relative $\mathrm{f}$ and $\mathrm{d}$ orbital contributions to $\mathrm{M}-\mathrm{Cl}$ covalency in $\mathrm{MCl}_{6}{ }^{2-}(\mathrm{M}=\mathrm{Ti}, \mathrm{Zr}, \mathrm{Hf}, \mathrm{U})$ and $\mathrm{UOCl}_{5}{ }^{-}$using $\mathrm{Cl} \mathrm{K}$-edge $\mathrm{X}$-ray absorption spectroscopy and time-dependent density functional theory. J. Am. Chem. Soc. 134, 5586-5597 (2012).

6. Hayton, T. W. Recent developments in actinide-ligand multiple bonding. Chem. Commun. 49, 2956-2973 (2013).

7. Neidig, M. L., Clark, D. L. \& Martin, R. L. Covalency in f-element complexes. Coord. Chem. Rev. 257, 394-406 (2013).

8. Kaltsoyannis, N. Does covalency increase or decrease across the actinide series? Implications for minor actinide partitioning. Inorg. Chem. 52, 3407-3413 (2013)

9. Lukens, W. W. et al. Quantifying the $\sigma$ and $\pi$ interactions between $\mathrm{U}(\mathrm{V})$ f orbitals and halide, alkyl, alkoxide, amide, and ketimide ligands. J. Am. Chem. Soc. 135, 10742-10754 (2013).

10. Spencer, L. P. et al. Tetrahalide complexes of the $\left[\mathrm{U}(\mathrm{NR})^{2] 2+}\right.$ ion: synthesis, theory, and chlorine K-edge X-ray absorption spectroscopy. J. Am. Chem. Soc. 135, 2279-2290 (2013).

11. Polinski, M. J. et al. Unusual structure, bonding and properties in a californium borate. Nat. Chem. 6, 387-392 (2014).

12. Jones, M. B. \& Gaunt, A. J. Recent developments in synthesis and structural chemistry of nonaqueous actinide complexes. Chem. Rev. 113, 1137-1198 (2013).

13. La Pierre, H. S. \& Meyer, K. Activation of small molecules by molecular uranium complexes. Prog. Inorg. Chem. 58, 303-416 (2014).

14. Liddle, S. T. The renaissance of non-aqueous uranium chemistry. Angew. Chem. Int. Ed. 54, 8604-8641 (2015).

15. Cary, S. K. et al. Emergence of californium as the second transitional element in the actinide series. Nat. Commun. 6, 6827 (2015)

16. Vitova, $\mathrm{T}$. et al. The role of the $5 \mathrm{f}$ valence orbitals of early actinides in chemical bonding. Nat. Commun. 8, 16053 (2017).

17. Formanuik, A. et al. Actinide covalency measured by pulsed electron paramagnetic resonance spectroscopy. Nat. Chem. 9, 578-583 (2017).

18. Cary, S. K. et al. Incipient class II mixed valency in a plutonium solid-state compound. Nat. Chem. 9, 856-861 (2017).

19. Kerridge, A. Quantification of f-element covalency through analysis of the electron density: insights from simulation. Chem. Commun. 53, 6685-6695 (2017).

20. Deacon, G. B., Gatehouse, B. M., Shen, Q. \& Ward, G. N. Organoamidoand Aryloxo-Lanthanides-VII. the X-ray structure of five-coordinate $\left[\mathrm{La}\left(\mathrm{OC}_{6} \mathrm{H}_{3} \mathrm{Ph}_{2}-2,6\right)_{3}(\mathrm{THF})_{2}\right] \cdot$ THF. Polyhedron 12, 1289-1294 (1993)

21. Cosgriff, J. E., Deacon, G. B. \& Gatehouse, B. M. Organoamido- and AryloxoLanthanoids. IX preparations and structures of Tris $\left(\eta^{2}-3,5\right.$-diphenylpyrazolato $)$ lanthanoid(III) complexes with triphenylphosphine oxide and tetrahydrofuran. Aust. J. Chem. 46, 1881-1896 (1993).

22. Deacon, G. B., Feng, T., Skelton, B. W. \& White, A. H. Organoamido- and Aryloxo-Lanthanoids. XI synthesis and crystal structures of $\mathrm{Nd}(\mathrm{Odpp})_{3}, \mathrm{Nd}$ $(\mathrm{Odpp})_{3}(\mathrm{thf})$ and $\left[\mathrm{Nd}(\mathrm{Odpp})_{3}\left(\mathrm{thf}_{2} \cdot 2(\mathrm{thf})\left(\mathrm{Odpp}^{-}=2,6\right.\right.\right.$-Diphenylphenolate $)$ variations in intramolecular $\pi$-Ph-Nd interactions. Aust. J. Chem. 48, 741-756 (1995). 
23. Freedman, D., Melman, J. H., Emge, T. J. \& Brennan, J. G. Cubane clusters containing lanthanide ions: $(\mathrm{py})_{8} \mathrm{Yb}_{4} \mathrm{Se}_{4}(\mathrm{SePh})_{4}$ and $(\mathrm{py})_{10} \mathrm{Yb}_{6} \mathrm{~S}_{6}(\mathrm{SPh})_{6}$. Inorg. Chem. 37, 4162-4163 (1998).

24. Rabe, G. W., Strissel, C. S., Liable-Sands, L. M., Concolino, T. E. \& Rheingold, A. L. Terphenyl ligand systems in lanthanide chemistry: synthesis and structural characterization of two 2,6-dimesitylphenyl derivatives of trivalent Ytterbium. Inorg. Chem. 38, 34463447 (1999).

25. Deacon, G. B., et al. Manipulation of reaction pathways in redox transmetallation-ligand exchange synthesis of lanthanoid(II/III) aryloxide complexes. Dalton Trans. 802-812 (2006).

26. Panda, T. K. et al. Imidazolin-2-iminato complexes of rare earth metals with very short metal-nitrogen bonds: experimental and theoretical studies. Inorg. Chem. 48, 5462-5472 (2009)

27. Krogh-Jespersen, K., Romanelli, M. D., Melman, J. H., Emge, T. J. \& Brennan, J. G. Covalent bonding and the trans influence in lanthanide compounds. Inorg. Chem. 49, 552-560 (2010).

28. Hamidi, S., Deacon, G. B., Junk, P. C. \& Neumann, P. Direct reaction of iodine-activated lanthanoid metals with 2,6-diisopropylphenol. Dalton. Trans. 41, 3541-3552 (2012).

29. Gholivand, K. \& Mahzouni, H. R. Trans influence and covalent bonding in a new octahedral lanthanum(III) complex of diphenylmorpholinyl phosphinamide. Inorg. Chim. Acta 386, 8-12 (2012).

30. Deacon, G. B., Hamidi, S., Junk, P. C., Kelly, R. P., Wang, J. Direct reactions of iodine-activated rare-earth metals with phenols of varying steric bulk. Eur. J. Inorg. Chem. 460-468 (2014).

31. Perrin, L., Maron, L. \& Eisenstein, O. Some structural and electronic properties of $\mathrm{MX}_{3}\left(\mathrm{M}=\mathrm{Ln}, \mathrm{Sc}, \mathrm{Y}, \mathrm{Ti}^{+}, \mathrm{Zr}^{+}, \mathrm{Hf}^{+} ; \mathrm{X}=\mathrm{H}, \mathrm{Me}, \mathrm{Hal}, \mathrm{NH}_{2}\right)$ from DFT calculations. Faraday Discuss. 124, 25-39 (2003).

32. Löble, M. W. et al. Covalency in lanthanides. An X-ray absorption spectroscopy and density functional theory study of $\mathrm{LnCl}_{6}{ }^{x-}(\mathrm{x}=3,2)$. J. Am. Chem. Soc. 137, 2506-2523 (2015).

33. La Pierre, H. S. \& Meyer, K. Uranium-ligand multiple bonding in uranyl analogues, $[\mathrm{L}=\mathrm{U}=\mathrm{L}]^{\mathrm{n}+}$, and the inverse trans influence. Inorg. Chem. 52, 529-539 (2013).

34. Bursten, B. E., Palmer, E. J. \& Sonnenberg, J. L. in Recent Advances in Actinide Science, Special Publications (eds. May, I., Bryan, N. D. \& Alvares, R.) (The Royal Society of Chemistry, London, 2006).

35. Kaltsoyannis, N., Hay, P. J., Li, J., Blaudeau, J.-P. \& Bursten, B. E. in The Chemistry of the Actinide and Transactinide Elements, 3rd edn. (eds. Morss, L. R., Edelstein, N. \& Fuger, J.) pp 1893-2012 (Springer, Dordrecht, 2006).

36. Streitwieser, A. Jr. \& Müller-Westerhoff, U. Bis(cyclooctatetraenyl)uranium (uranocene): A new class of sandwich complexes that utilizes atomic forbitals. J. Am. Chem. Soc. 90, 7364-7374 (1968).

37. Rösch, N. \& Streitwieser, A. Jr. Quasirelativistic SCF-Xa scattered-wave study of uranocene, thorocene, and cerocene. J. Am. Chem. Soc. 105, 7237-7240 (1983).

38. Chang, A. H. H. \& Pitzer, R. M. Electronic structure and spectra of uranocene. J. Am. Chem. Soc. 111, 2500-2507 (1989).

39. Bursten, B. E., Rhodes, L. F. \& Strittmatter, R. J. Bonding in tris $\left(\eta^{5}-\right.$ cyclopentadienyl) actinide complexes. The ground electronic configurations of "base-free" $\mathrm{Cp}_{3} \mathrm{An}$ complexes $(\mathrm{An}=$ thorium, protactinium, uranium, neptunium, plutonium). J. Am. Chem. Soc. 111, 2756-2758 (1989).

40. Strittmatter, R. J. \& Bursten, B. E. Bonding in tris $\left(\eta^{5}\right.$-cyclopentadienyl) actinide complexes. A comparison of the bonding in $\mathrm{Np}, \mathrm{Pu}$, and transplutonium compounds and with that in lanthanide compounds and a transition-metal analogue. J. Am. Chem. Soc. 113, 552-559 (1991).

41. Li, J. \& Bursten, B. E. Electronic structure of cycloheptatrienyl sandwich complexes of actinides: $\mathrm{An}\left(\eta^{7}-\mathrm{C}_{7} \mathrm{H}_{7}\right)_{2}(\mathrm{An}=\mathrm{Th}, \mathrm{Pa}, \mathrm{U}, \mathrm{Np}, \mathrm{Pu}, \mathrm{Am})$. J. Am. Chem. Soc. 119, 9021-9032 (1997).

42. King, D. M. et al. Synthesis and structure of a terminal uranium nitride complex. Science 337, 717-720 (2012).

43. King, D. M. et al. Isolation and characterization of a uranium(VI)-nitride triple bond. Nat. Chem. 5, 482-488 (2013).

44. Tatsumi, K. \& Hoffmann, R. Bent Cis $\mathrm{d}^{0} \mathrm{MoO}_{2}{ }^{2+}$ vs. linear trans $\mathrm{d}^{0} \mathrm{f}^{0} \mathrm{UO}_{2}{ }^{2+}$ : a significant role for nonvalence $6 \mathrm{p}$ orbitals in uranyl. Inorg. Chem. 19 2656-2658 (1980).

45. Denning, R. G. Electronic structure and bonding in actinyl ions. Struct. Bond. (Berl.) 79, 215-276 (1992).

46. Denning, R. G. Electronic structure and bonding in actinyl ions and their analogs. J. Phys. Chem. A 111, 4125-4143 (2007).

47. Butcher, R. J., Penfold, B. R. \& Sinn, E. Crystal structures of cisdibromodioxobis(triphenylphosphine oxide)molybdenum(VI), cis dichlorodioxobis(triphenylphosphine oxide)molybdenum(VI), and cis-bis (butane-2,3-diolato)dioxomolybdenum(VI)-butane-2,3-diol (1/2): a comparison of co-ordination spheres and the general stereochemistry of molybdenum(VI) oxo-complexes. J. Chem. Soc. Dalton Trans. 668-675 (1979).
48. Bombieri, G., Forsellini, E., Day, J. P. \& Azeez, W. I. Crystal and molecular structure of dichlorodioxobis(triphenylphosphine oxide)uranium(VI). J. Chem. Soc. Dalton Trans. 677-680 (1978).

49. Vitova, T. et al. Dehydration of the uranyl peroxide studtite, $\left[\mathrm{UO}_{2}\left(\eta^{2}-\mathrm{O}_{2}\right)\right.$ $\left.\left(\mathrm{H}_{2} \mathrm{O}\right)_{2}\right] \cdot{ }_{2} \mathrm{H}_{2} \mathrm{O}$, affords a drastic change in the electronic structure: a combined $\mathrm{X}$-ray spectroscopic and theoretical analysis. Inorg. Chem. 57, 1735-1743 (2018).

50. Dyall, K. G. Bonding and bending in the actinyls. Mol. Phys. 96, 511-518 (1999).

51. Kosog, B., La Pierre, H. S., Heinemann, F. W., Liddle, S. T. \& Meyer, K. Synthesis of Uranium(VI) terminal oxo complexes: molecular geometry driven by the inverse trans-influence. J. Am. Chem. Soc. 134, 5284-5289 (2012).

52. Lam, O. P. et al. Observation of the inverse trans influence (ITI) in a uranium (V) imide coordination complex: an experimental study and theoretical evaluation. Inorg. Chem. 51, 6190-6199 (2012).

53. King, D. M. et al. Single-molecule magnetism in a single-ion triamidoamine Uranium(V) terminal mono-oxo complex. Angew. Chem. Int. Ed. 52, 4921-4924 (2013).

54. Lewis, A. J., Carroll, P. J. \& Schelter, E. J. Stable Uranium(VI) methyl and acetylide complexes and the elucidation of an inverse trans influence ligand series. J. Am. Chem. Soc. 135, 13185-13192 (2013).

55. Lewis, A. J., Mullane, K. C., Nakamaru-Ogiso, E., Carroll, P. J. \& Schelter, E. J. The inverse trans influence in a family of pentavalent uranium complexes. Inorg. Chem. 53, 6944-6953 (2014).

56. La Pierre, H. S. et al. Charge control of the inverse trans-influence. Chem. Commun. 51, 16671-16674 (2015).

57. O'Grady, E. \& Kaltosyannis, N. On the inverse trans influence. Density functional studies of $\left[\mathrm{MOX}_{5}\right] \mathrm{n}-{ }_{-}(\mathrm{M}=\mathrm{Pa}, \mathrm{n}=2 ; \mathrm{M}=\mathrm{U}, \mathrm{n}=1 ; \mathrm{M}=\mathrm{Np}$, $\mathrm{n}=0 ; \mathrm{X}=\mathrm{F}, \mathrm{Cl}$ or Br). J. Chem. Soc. Dalton Trans. 1233-1239 (2002).

58. Kovács, A. \& Konings, R. J. M. A theoretical study of the structure and bonding of $\mathrm{UOX}_{4}(\mathrm{X}=\mathrm{F}, \mathrm{Cl}, \mathrm{Br}, \mathrm{I})$ molecules: the importance of inverse trans influence. Chemphyschem 7, 455-462 (2006).

59. Chermette, H., Rachedi, K. \& Volatron, F. Trans effect and inverse trans effect in $\mathrm{MLX}_{5}$ complexes $(\mathrm{M}=\mathrm{Mo}, \mathrm{U} ; \mathrm{L}=\mathrm{O}, \mathrm{S} ; \mathrm{X}=\mathrm{Cl}, \mathrm{Br})$ : a rationalization within density functional theory study. THEOCHEM 762, 109-121 (2006).

60. Gregson, M. et al. A cerium(IV)-carbon multiple bond. Angew. Chem. Int. Ed. 52, 13016-13019 (2013).

61. Gregson, M. et al. Emergence of comparable covalency in isostructural cerium (IV) and uranium(IV)-carbon multiple bonds. Chem. Sci. 7, 3286-3297 (2016).

62. Gregson, M. et al. The inverse-trans-influence in tetravalent lanthanide and actinide bis(carbene) complexes. Nat. Commun. 8, 14137 (2017).

63. Lu, E., Tuna, F., Lewis, W., Kaltsoyannis, N. \& Liddle, S. T. Uranium metallaallenes with carbene imido $\mathrm{R}_{2} \mathrm{C}=\mathrm{U}^{\mathrm{IV}}=\mathrm{NR}$ ' Units $\left(\mathrm{R}=\mathrm{Ph}_{2} \mathrm{PNSiMe}_{3} ; \mathrm{R}^{\prime}=\right.$ $\mathrm{CPh}_{3}$ ): alkali metal-mediated push-pull effects with an amido auxiliary. Chem. Eur. J. 22, 11554-11558 (2016).

64. Lu, E. et al. Uranium-carbene-imido metalla-allenes: ancillary-ligandcontrolled Cis-/Trans-isomerisation and assessment of Trans-influence in the $\mathrm{R}_{2} \mathrm{C}=\mathrm{U}^{\mathrm{IV}}=\mathrm{NR}$ ' Unit $\left(\mathrm{R}=\mathrm{Ph}_{2} \mathrm{PNSiMe}_{3} ; \mathrm{R}^{\prime}=\mathrm{CPh}_{3}\right)$. Chem. Eur. J. 22, 11559-11563 (2016)

65. Ren, W., Deng, X., Zi, G. \& Fang, D.-C. The Th $=$ C double bond: an experimental and computational study of thorium poly-carbene complexes. Dalton. Trans. 40, 9662-9664 (2011).

66. Scarnorough, C. C. \& Wieghardt, K. Electronic structure of 2,2'-bipyridine organotransition-metal complexes. Establishing the ligand oxidation level by density functional theoretical calculations. Inorg. Chem. 50, 9773-9793 (2011)

67. Frisch, M. J. et al. Gaussian 09, Revision D.01 (Gaussian, Inc., Wallingford, CT, 2016)

68. Perdew, J. P., Burke, K. \& Ernzerhof, M. Generalized gradient approximation made simple. Phys. Rev. Lett. 77, 3865-3868 (1996).

69. Perdew, J. P., Burke, K. \& Ernzerhof, M. Erratum to generalized gradient approximation made simple. Phys. Rev. Lett. 78, 1396-1396 (1997).

70. Adamo, C. \& Barone, V. Toward reliable density functional methods without adjustable parameters: the PBE0 model. J. Chem. Phys. 110, 6158-6170 (1999).

71. Reta, D. et al. The performance of density functional theory for the description of ground and excited state properties of inorganic and organometallic uranium compounds. J. Organomet. Chem. 857, 58-74 (2018).

72. $\mathrm{Wu}, \mathrm{Q}$.-Y. et al. Insight into the nature of $\mathrm{M}-\mathrm{C}$ bonding in the lanthanide/ actinide-biscarbene complexes: a theoretical perspective. Dalton. Trans. 47, 12718-12725 (2018)

73. Glendening, J. K. et al. NBO 6.0 (Theoretical Chemistry Institute, University of Wisconsin, Madison, 2013).

74. Bader, R. F. W. Atoms in Molecules: A Quantum Theory (Oxford University Press, Oxford, 1990).

75. Keith, T. A. TK Gristmill Software (Overland Park KS, USA, 2014). 


\section{Acknowledgements}

We thank the ERC (grant GoG612724), EPSRC (grants EP/P001386/1, EP/M027015, EP/N021932), Marie Curie Incoming Fellowship Scheme (grant 297888), and the University of Manchester for support, and the University of Manchester's Computational Shared Facility for computational resources. We are also grateful to the Pakistan HEC for IRSIP funding to S.S.

\section{Author Contributions}

E.L. prepared the compounds and recorded and interpreted the characterisation data. S.S. and V.E.J.B. conducted and interpreted the theoretical calculations. N.K. directed and analysed the computational work and developed the central research idea. A.J.W. collected, solved, and refined the X-ray crystallographic data. S.T.L. originated and developed the central idea, analysed all the data, and wrote the manuscript with contributions from all co-authors.

\section{Additional information}

Supplementary Information accompanies this paper at https://doi.org/10.1038/s41467019-08553-y.

Competing interests: The authors declare no competing interests.

Reprints and permission information is available online at http://npg.nature.com/ reprintsandpermissions/
Journal peer review information: Nature Communications thanks Tonya Vitova, Weiqun Shi, and the anonymous reviewer for their contribution to the peer review of this work. Peer reviewer reports are available.

Publisher's note: Springer Nature remains neutral with regard to jurisdictional claims in published maps and institutional affiliations.

(c) (i) Open Access This article is licensed under a Creative Commons Attribution 4.0 International License, which permits use, sharing, adaptation, distribution and reproduction in any medium or format, as long as you give appropriate credit to the original author(s) and the source, provide a link to the Creative Commons license, and indicate if changes were made. The images or other third party material in this article are included in the article's Creative Commons license, unless indicated otherwise in a credit line to the material. If material is not included in the article's Creative Commons license and your intended use is not permitted by statutory regulation or exceeds the permitted use, you will need to obtain permission directly from the copyright holder. To view a copy of this license, visit http://creativecommons.org/ licenses/by/4.0/.

(c) The Author(s) 2019 